\title{
Research on the Culture Introduction in the Teaching of French as a
}

\section{Second Foreign Language}

\author{
Wu Hui ${ }^{1, a}$ \\ ${ }^{1}$ School of Foreign Languages, Wuhan Textile University, Wuhan, Hubei, 430073, China \\ a email:
}

Keywords: French as a Second Foreign Language, Culture Teaching, Language Teaching

\begin{abstract}
The formation and development of each language have a very close relationship with the cultural background of the whole society. Therefore, in the teaching of French as a second foreign language, teachers should not only be limited to the teaching of book knowledge, but also pay attention to the introduction of cultural factors. Based on the author's teaching experience, this paper first discussed the necessity of cultural teaching in French as a second foreign language, then analyzed the role of cultural teaching, and finally it puts forward the method of culture teaching in the French class. The results of this study has a certain effect on improving the teaching effect of French as a second foreign language.
\end{abstract}

\section{Introduction}

Language is not only the sum of the vocabulary, voice and grammar, but also a tool for human social communication. In the history of human development, language has always been with the development of culture. The formation and development of each language are closely related to the specific circumstances of the society. In the long historical development, different ethnic groups have accumulated a unique culture, which is bound to be reflected in their language. Therefore, for foreign language teachers, the teaching of the language is also a teaching of culture. It is necessary to guide and help students to understand the social and cultural background of the generation and use of this language, to correctly understand and use the language. French teaching, if only limited to the speech, words and syntax, is bound to be unsuccessful in teaching.

\section{The Necessity to Introduce Culture Teaching in French as a Second Foreign Language}

Language is the product of its culture. People's words and deeds reflect certain social and cultural connotation, and their language structure, communication model are influenced and restricted by the culture of the nation to a certain degree. The French nation has a history of over two thousand years, and the specific natural, social and historical conditions created perplexing personality of the French. In the teaching of French as a second foreign language, teachers should not only pay attention to the cultivation of students' listening, reading, writing and translation skills, but ignore the teaching of culture. In the process of learning French, if the students do not understand the specific social and cultural environment in France, they can not understand its true meaning. For example: the phrase of "dresser des barricades" in French, literally means "built barricades", but for the French, the this phrase can be understood from the revolt and fight, because 
in the history of France, in June 5, 1832, in the people's uprising led by the organization of the Republican Party, the Paris people were against government forces by building the barricade. There is a proverb in France, "Un repas sans fromage est comme une journée sans soleil", it means if a meal without cheese is like a day without sun. People who know the French culture know that cheese is one of the main foods of the French. From these two sentences, it is not difficult for us to find that social and cultural factors have a special role in the expression of French. Therefore, it needs to pay attention to the teaching of cultural background knowledge in teaching, reveal the cultural factors behind the language, which can lead to misunderstanding and conflict, to make the students know the real French, understand the French thinking patterns and expressions, so as to grasp the authentic French.

\section{The Role of Culture Teaching in the Teaching of French as a Second Foreign Language}

Improving students' interest in learning French. France has a long history and culture,and it is inextricably linked with the ancient Greece, ancient Rome culture, is a bright pearl in the treasure house of human culture. A lot of English majors have chosen French as a second foreign language with their curiosity and love in French and French history and culture. French teachers' responsibilities, is to put these students into another world for them, as they open a window to understand the world. If teachers only teach the word syntax, ignore the cultural factors hidding behind the language, students may gradually lose their interest in learning French and enthusiasm. in some teachers' teaching course,they pay too much attention to the memory of words and grammatical structure, while the introduction of the French culture is rare and less. On the contrary, some teachers are good at the analysis of difference of Sino French culture, to seize the difficulty caused by the understanding of cultural differences in teaching. This French lesson is interesting, so that students are willing to accept.

To improve students' ability to communicate in French. Like other foreign language learning, it is more important to be able to use French in addition to learning the grammatical structure and the necessary vocabulary. In 1972, the American sociologist Hymes put forward the concept of "communicative competence". Since then many linguists generally believe that in addition to the training and development of students' language skills, it also needs to cultivate their cultural competence. Reflected in the French, that is, the actual use of French, with the French speaking countries, the ability to carry out normal communication. Because there are differences in different cultures in the value orientation, life style, thinking habits, and many other aspects, people's language can only be understood in a certain social and cultural contexts. For example, after serving the French, in order to express gratitude, the French used to say: merci. According to the French custom, we should answer: "Je vous en prie." But in accordance with their own thinking patterns and language habits, some Chinese people answer: "Vous êtes les bienvenus, ce que je dois faire." According to the French understanding, the answer to this question means they have no alternative against his will. Therefore, the French language teaching should not only be limited to the language system itself, but also should be related to the teaching language of the appropriate cultural background knowledge.

\section{Method for Culture Teaching in the French Class}

Introducing cultural differences to improve students' cultural awareness. In the course of teaching, teachers should introduce the cultural background, to enable students to understand the actual situation of the French speaking countries, to learn to use appropriate French to express their 
ideas in appropriate occasions. Only through the comparison between Chinese and Western culture, can we form a kind of potential reaction ability in the students' minds. "entre la poire et le fromage" means a leisure time, which is determined by the different diet culture between China and France. After the meal, the Chinese people used to drink tea, while the French people used to taste the fruit and cheese. The cultivation and improvement of this ability needs to introduce the differences between Chinese and Western culture teachers in the teaching process to make the students consciously eliminate the interference of national culture.

Comparing the difference between Chinese and Western culture. To cultivate and enhance students' sensitivity to Chinese and Western culture is an important task in the teaching of French. Neglecting or despising this result in the situation only learning pronunciation, grammar rules, vocabulary knowledge of these simple language. This result affects the students' pragmatic competence, which makes the students can't use French communicative activities properly and flexibly, and even make mistakes due to cultural differences. For example, a French friend said to a Chinese student: "Tu parles bien français", and he student is busy answering: "Non, mon français est mauvais, je dois bien étudier le français". Although the sentence grammar is correctly, it is not in accordance with the French custom. The error caused by the cultural difference is more serious than that of the language, and the student only needs to say "Merci".

Improving the French level of Teachers. The teacher's French level is not simply to stay in listening, speaking, reading, writing, and translating, but it needs to rise to the French culture of a sincere love and understanding. For a long period of time, France was the cultural center of Europe and the whole of the West. French novel, film, fashion, perfume, music, food have played an important role in the world, and these are exactly what the students are interested in. If teachers only teach French words and grammar, with very little of this cultural background content knowledge, ignoring the cultural knowledge, then the students will feel boring, and the goal of cross-cultural communication is difficult to achieve. French weekly hours is not much, so teachers should constantly improve their own level of French, in-depth understanding and study of French history and culture to integrate the culture into the teaching in very limited class time.

Setting specific context in classroom teaching. In order to improve the language ability of students, some teachers usually let students make sentences. However, the practice can not meet the needs of students, but in the implementation of the specific context, students do not know how to apply correctly. In this case, teachers can organize a number of classroom discussions, and the content can be involved in all aspects of French social culture, such as France's education, sports, music, movies, transportation and so on. Students are interested in these topics, so it can stimulate their desire to speak. In addition, teachers can also encourage students to simulate live scenes to perform, rehearsal sketches, and actively organize the whole process of teaching into a near real communicative activities, so that students can understand what to say in different scenarios. These methods are very helpful to train students' ability of expression. A lively discussion, lively performances can help students to master the language, to accumulate a more personal experience of the French social culture.

\section{Conclusion}

Language is part of culture, and culture must be recorded and reflected with the aid of a language, so in French teaching, we should pay more attention to the comparative analysis of the cultural differences between China and France, and fully tap the cultural connotation of the Chinese and Western culture. Therefore, the French teachers should have a thorough grasp for the social culture of France, continue to learn, constantly improve their own cultural accomplishment, constantly 
update knowledge, to enable students to form a strong cross-cultural communication skills.

\section{References}

[1] Pei Guangyu. Cultural teaching in French [J]. China Electric Power Education, 2009,12:217-218.

[2] Hao Xiaoli. The daily culture teaching in French [J]. Journal of Jinzhong University, 2006,05:57-59.

[3] Fan Jing. Exploration into the cultural factors in the teaching of French[J]. exam week, 2009,29:338-339.

[4] Cai Suying, Ding Hua. Cultural teaching in French's teaching[J]. Science and technology information, 2010,32:564. 